\title{
"GIRLS BEHAVING BADLY?" YOUNG FEMALE ViOLENCE IN NEW ZEALAND
}

\author{
Nessa Lynch*
}

While female crime, and particularly young female violence, has long been a titillating subject for the media, recent reports suggest an upsurge in violence amongst girls in New Zealand. This short article uses raw apprehension and sentencing data to consider the question of whether violence by girls is indeed increasing. It is concluded that while there does seem to have been an increase in violence by girls in the earlier part of the decade, the level of violence has fallen in the last three years. There may also be other explanations for an increase in apprehensions for violent offences such as changes in Police practice and societal attitudes.

\section{INTRODUCTION}

The situation of girls ${ }^{1}$ in conflict with the law in New Zealand is a notably under-researched aspect of the youth justice system. In this short article, I consider the question of whether offending by girls, particularly violent offending, is indeed on the increase, as is commonly portrayed in the media. First, I set the context by reviewing the literature, noting the lack of research on the background and experiences of girls in the criminal justice system in New Zealand. I discuss the historical and contemporary construction of girls' violence in the popular media. I analyse the raw data on apprehension and sentencing trends to conclude that while there is some evidence that apprehensions for violent offending are increasing, a moral panic is unjustified and is largely based on anecdote rather than evidence. I place the statistics in context, particularly that apprehensions of girls make up a small minority of child and youth apprehensions. I suggest other possible reasons for increasing apprehensions, including Police decision making and changes in societal attitudes. I

* Senior Lecturer, Faculty of Law, Victoria University of Wellington. My thanks to Elena Mok for her careful and diligent research assistance, particularly with obtaining statistics.

1 I use the term "girls" to describe those within the ambit of the youth justice system, ie 10-16 year olds. The age of penal majority in New Zealand is 17. In this, New Zealand is out of step with ages of penal majority in comparable jurisdictions and does not accord with the definition of "child" in the United Nations Convention on the Rights of the Child CRC 1577 UNTS 3 (opened for signature 20 November 1989 entered into force 2 September 1990), art 1. See Nessa Lynch "Youth Justice in New Zealand: A children's rights perspective" (2008) 8 Youth Justice at 215-228. 
conclude by critiquing the lack of specific research on the situation of girls in the youth justice system in New Zealand.

\section{SETTING THE CONTEXT}

Feminist criminology has been an established discipline since the $1970 \mathrm{~s}^{2}$ critiquing the malecentric focus of research and policy, and the view of female criminality as biologically determined. ${ }^{3}$ As Chesney-Lind notes, for most of the 20th century "girls and women in conflict with the law were overlooked or excluded in mainstream works while demonized, masculinized, and sexualized in the marginalized literature that brooded on their venality". ${ }^{4}$

Internationally, there has been considerable treatment of the special situation of girls in conflict with the law. The literature has examined changing portrayals of the causes of juvenile female offending, ${ }^{5}$ the importance of specific rehabilitation and re-integrative programmes, ${ }^{6}$ and changing socio-political attitudes to this group of young offenders. ${ }^{7}$ The professional response to female offending has historically been "welfare-oriented", and essentially a "proxy" for public concerns

2 See Carol Smart Women, Crime and Criminology: A Feminist Critique (Routledge and Kegan Paul, London, 1976); Ngaire Naffine Feminism and Criminology (Polity Press, Cambridge, 1997); Maureen Cain "Towards Transgression: New Directions in Feminist Criminology" (1990) 18 International Journal of the Sociology of Law 1.

3 See Ann Lloyd Doubly Deviant, Doubly Damned: Society's Treatment of Violent Women (Penguin Books, London, 1995).

4 Meda Chesney-Lind "Patriarchy, Crime, and Justice: Feminist Criminology in an Era of Backlash" (2006) 1 Feminist Criminology 6 at 7.

5 Lisa Pasko "Damaged Daughters: The History of Girls' Sexuality and the Juvenile Justice System" (2010) 100 J Crim L \& Criminology 1099; Anne Worrall "Girls At Risk? Reflections On Changing Attitudes To Young Women's Offending" (2001) 48 Probation Journal 86.

6 See Craig Dowden and Don A Andrews "What Works for Female Offenders: A Meta-Analytic Review" (1999) 45 Crime \& Delinquency 438; Meda Chesney-Lind, Merry Morash and Tia Stevens "Girls Troubles, Girls' Delinquency, and Gender Responsive Programming: A Review" (2008) 41 Australian \& New Zealand Journal of Criminology 162; M Baines and C Alder "Are Girls More Difficult to Work With? Youth Workers' Perspectives in Juvenile Justice and Related Areas" (1996) 42 Crime \& Delinquency 467.

7 Meda Chesney-Lind "Girls' Crime and Woman's Place: Toward a Feminist Model of Female Delinquency" (1989) 35 Crime \& Delinquency 5; Anne Worrall "Troubled or Troublesome? Justice for Girls and Young Women" in B Goldson (ed) Youth Justice: Contemporary Policy and Practice (Ashgate Publishing Ltd, Aldershot, 1999) 28; Anne Worrall "Governing Bad Girls: Changing Constructions of Adolescent Female Delinquency" in Jo Bridgeman and Daniel Monk (eds) Feminist Perspectives on Child Law (Cavendish Publishing, London, 2000) 151; K Carrington Offending Girls (Allen \& Unwin, New South Wales, 1993). 
about female sexuality and the declining moral fabric of society. ${ }^{8}$ There has been a tendency to consider female youth offending through the lens of gender rather than age, with the result that traditional theories about female delinquency "virtually ignored girls and their problems or misrepresented them" and responses within the youth justice system to girls were primarily shaped by wider social expectations of female conduct. ${ }^{9}$ Concerns were also expressed by youth justice practitioners throughout the literature regarding the difficulty of working with girls due to their perceived verbally and sexually aggressive behaviour, and tendency to manipulate and be dishonest. ${ }^{10}$ There has, however, been a gradual shift towards redefining female delinquency as "criminal", ${ }^{11}$ and recognition of the need for gender-specific services for girls which address their particular risk factors and experiences. ${ }^{12}$ It has been recognised that frequently girls in conflict with the law are not only perpetrators but have themselves frequently undergone extensive victimisation. ${ }^{13}$

Moving to the New Zealand context, there is a considerable body of research on the adult female experience with crime and the criminal justice system. Research has considered the woman as victim/survivor or witness, ${ }^{14}$ and the particular situation of the woman as battered defendant has

8 Worrall "Governing Bad Girls: Changing Constructions of Female Juvenile Delinquency", above n 7, at $152-153$.

9 Loraine Gelsthorpe and Anne Worrall "Looking for Trouble: A Recent History of Girls, Young Women and Youth Justice" (2009) 9 Youth Justice 209 at 220.

10 See HC Brown and J Pearce "Good practice in the face of anxiety: social work with girls and young women" (1992) 6 JSWP 159; Baines and Alder, above n 6; Christine M Alder "'Passionate and Willful' Girls: Confronting Practices" (1998) 9(4) Women and Criminal Justice 81; Worrall "Governing Bad Girls: Changing Constructions of Female Juvenile Delinquency", above n 7; SA Batchelor and MJ Burman "Working with girls and young women" in Gill McIvor (ed) Women Who Offend (Jessica Kingsley Publishers, London, 2004) 266.

11 Worrall "Governing Bad Girls: Changing Constructions of Female Juvenile Delinquency", above n 7, at 153.

12 See Kaye L McLaren Tough is not Enough - Getting Smart about Youth Crime (Ministry of Youth Affairs, June 2000) at 33 .

13 Batchelor and Burman, above n 10, at 276

14 See for example Elisabeth McDonald and Yvette Tinsley (eds) From "Real Rape" to Real Justice: Prosecuting Rape in New Zealand (Victoria University Press, Wellington, 2011); Eric Pawson and Glenn Banks "Rape and fear in a New Zealand city" (1993) 25 Area 55; Kelsey Hegarty and Gwenneth Roberts "How common is domestic violence against women? The definition of partner abuse in prevalence studies" (1998) 22(1) Australian and New Zealand Journal of Public Health 49; Ruth Panelli, Jo Little and Anna Kraack "A Community Issue? Rural Women's Feelings of Safety and Fear in New Zealand" (2004) 11 Gender, Place \& Culture 445. 
received considerable attention at an academic and policy level. ${ }^{15}$ It is arguable that the experiences of woman as offender or prisoner are less examined. ${ }^{16}$

It is apparent however that the particular needs and interests of girls in conflict with the law is a rarely considered topic in this jurisdiction. A literature search revealed a paucity of published research on offending by, or treatment of young female offenders in New Zealand. Two recent examples of primary research which seek to fill this lacuna are Swift's examination of girls' violence and anti-social behaviour (both in the schoolyard and in a criminal sense) in the Nelson-Tasman region, ${ }^{17}$ and Goldingay, who carried out primary research on the experiences of girls and young women in New Zealand prisons with a focus on the implications of age-mixing. ${ }^{18}$ There is also a comprehensive series of scientific articles resulting from the Dunedin Health and Multidisciplinary Study, ${ }^{19}$ some of which deal particularly with young female offenders. ${ }^{20}$

15 Elizabeth Sheehy, Julie Stubbs and Julia Tolmie "Battered women charged with homicide in Australia, Canada and New Zealand: How do they fare?" (2012) 45 Australian \& New Zealand Journal of Criminology 383. Ruth Busch and Neille Robertson "The Gap Goes On: An Analysis of Issues Under the Domestic Violence Act 1995" (1997) 17 NZULR 337; Elisabeth McDonald "Defending Abused Women: Beginning a Critique of New Zealand Criminal Law" (1997) 27 VUWLR 673; Bruce Robertson "Battered Woman Syndrome: Expert Evidence in Action" (1998) 9 Otago LR 277; Law Commission Some Criminal Defences with Particular Reference to Battered Defendants (NZLC R73, 2001); Elizabeth Sheehy, Julie Stubbs and Julia Tolmie. "Defending Battered Women on Trial: The Battered Woman Syndrome and its Limitations" (1992) 16 Criminal LJ 369.

16 Ronda Bungay Scarecrows: why women kill (Random House, Auckland, 1998); Rachael M Collie and Devon LL Polaschek "Sorting Women's Risk: New Zealand Women Prisoners' Misconducts and Internal Security Risk" (2003) 32 New Zealand Journal of Psychology 101; Max W Abbott and Brian G McKenna "Gambling and Problem Gambling Among Recently Sentenced Women in New Zealand Prisons" (2005) 21(4) Journal of Gambling Studies 559; Deborah Mackenzie Arrested Female Offenders In Auckland City April-September 2008 (Preventing Violence in the Home, April 2009).

17 Donna Swift The Girls' Project. Girl Fighting: An investigation of young women's violent and anti-social behaviour (Stopping Violence Services, Nelson, 2011).

18 S Goldingay "Separation or Mixing: Issues for Young Women Prisoners in Aotearoa New Zealand Prisons" (thesis submitted for Degree of Doctor of Philosophy in Social Work, University of Canterbury, 2009). See also S Goldingay "Jail Mums: The Status of Adult Female Prisoners Among Young Female Prisoners in Christchurch Women's Prison" (2007) 31 Social Policy Journal of New Zealand 56.

19 Dunedin Multidisciplinary Health \& Development Research Unit <dunedinstudy.otago.ac.nz>.

20 See for example Avshalom Caspi and others "Unraveling Girls' Delinquency: Biological, Dispositional, and Contextual Contributions to Adolescent Misbehavior" (1993) 29 Developmental Psychology 19; David Fergusson, M L Horwood and Daniel S Nagin "Offending Trajectories in a New Zealand Birth Cohort" (2000) 38 Criminology 525. 


\section{THE CONSTRUCTION OF GIRLS' OFFENDING}

Female criminality, and particularly that of girls, has long been a titillating subject for the popular media. ${ }^{21}$ Two particular historical examples from New Zealand are illustrative of common themes. The Mazengarb Report was commissioned in response to reports of moral delinquency amongst minors in the Hutt Valley region of Wellington in the early 1950s. ${ }^{22}$ Despite charges stemming from the incidents involving charges of illegal sexual activity with underage girls, ${ }^{23}$ the Report placed considerable blame with the girls themselves.

The Final Report opined that: ${ }^{24}$

It is unfortunate that in many cases girls, by immodest conduct, have become the leaders in sexual misbehaviour and have in many cases corrupted the boys. ... Another disturbing feature is that in the case of boys more than half were committing their first offence, whereas only one-fifth of the girls were offending for the first time ... The following extract from the evidence of a headmaster is impressive of this new feature:

... We have not the same worry about boys as we have about girls. The worst cases we have are girls, and it is quite clear some of them are an absolute menace. They have dragged boys into this sort of thing. In general the girls are far worse than the boys.

Contemporaneously, the murder of a Christchurch mother at the hands of her teenage daughter and her daughter's best friend, shocked the nation, particularly the insinuations of a lesbian relationship between the two offenders. ${ }^{25}$ The calculating nature of the crime - the two offenders

21 Meda Chesney-Lind "Beyond Bad Girls: Feminist Perspectives on Female Offending" in Colin Sumner (ed) The Blackwell Companion to Criminology (Blackwell Publishing, Oxford, 2004) 255; Kathryn Ann Farr "Women on death row: Media representations of female evil" in Dena Elisabeth Eber and Arthur G Neal (eds) Memory and representation: Constructed truths and competing realities (Popular Press, Kentucky, 2001) 73; Meda Chesney-Lind and Michele Eliason "From invisible to incorrigible: The demonization of marginalized women and girls" (2006) 2 Crime, Media, Culture 29; Meda Chesney-Lind "Media Misogyny: Demonizing 'Violent' Girls and Women" in Jeff Ferrell and Neil Websdale (eds) Making Trouble: Cultural Constructions of Crime, Deviance, and Control (Aldine de Gruyter, New York, 1999) 115.

22 OC Mazengarb "Report of the Special Committee on Moral Delinquency in Children and Adolescents" [1954] AJHR H-47 [Mazengarb Report].

23 Mazengarb Report, above n 22, at 18.

24 Mazengarb Report, above n 22, at 18. For a contemporary perspective on the issue, see Laurie Guy "'Moral Panic' or Pejorative Labelling? Rethinking the Mazengarb Inquiry into Underage Sex in the Hutt Valley in 1954" (2009) 33 Journal of Religious History 435.

25 James Bennett "Fifty Years of Parker and Hulme: A Survey of Some Major Textual Representations and Their Ideological Significance" (2006) 4 Journal of New Zealand Studies 11; James Bennett "Medicine, Sexuality, and High Anxiety in 1950s New Zealand: Peter Jackson's 'Heavenly Creatures' (1994)" (2006) 8(2) Health and History 147. 
had calmly planned the murder for a considerable amount of time with the apparent objective of spending more time together - was particularly shocking to the public. ${ }^{26}$

These cases are demonstrative of two longstanding themes in the popular portrayal of offending by girls. First, that girls' offending may arise from deviant sexuality which acts as a corrupting influence on boys. Secondly, that girls' offending is more likely to be calculated and cruel, ${ }^{27}$ while boys' violence is habitually portrayed as quasi-natural. ${ }^{28}$ Prevalent also is the "liberation hypothesis". ${ }^{29}$ This was first proposed in the 1960s/1970s in the context of a moral panic linking the women's liberation movement to increase in crime. ${ }^{30}$ This theory holds inter alia that "liberation" from traditional gender roles would lead to more violent offending by women, and that the level and frequency of such offending would gradually catch up with the male rate. ${ }^{31}$

A search for contemporary articles in New Zealand online newspaper archives revealed some familiar and some newer themes in the popular portrayal of girls' violence. Contemporary media coverage portrays girls' violence as increasing in frequency and gravity. ${ }^{32}$ A March 2013 article in the Christchurch Press newspaper (entitled "Girls Behaving Badly") informed its readers that: ${ }^{33}$

26 Bennett "Fifty Years of Parker and Hulme: A Survey of Some Major Textual Representations and Their Ideological Significance", above n 25.

27 Coretta Phillips "Who's Who in the Pecking Order? Aggression and 'Normal Violence' in the Lives of Girls and Boys" (2003) 43 Brit J Criminol 710 at 715.

28 See Myriam Miedzian Boys Will Be Boys: Breaking the Link Between Masculinity and Violence (Lantern Books, New York, 2002) at 16 and 58.

29 Nancy C Jurik and Russ Winn "Gender and Homicide: A Comparison of Men and Women Who Kill" (1990) 5 Violence and Victims 227 at 228.

30 Freda Adler, Herbert Marcus Adler and Hoag Levins Sisters in Crime: The Rise of the New Female Criminal (McGraw-Hill, New York, 1975); Smart, above n 2.

31 See Roy L Austin "Liberation and Female Criminality in England and Wales" (1981) 21 Brit J Criminol 371; Carol Smart "The New Female Criminal: Reality or Myth?" (1979) 19 Brit J Criminol 50; Joseph G Weis "Liberation and Crime: The Invention of the New Female Criminal" (1976) 6 CSJ 17.

32 See Simon Collins and Vaimoana Tapaleao "Schoolgirls 'more violent than boys'" Rotorua Daily Post (online ed, Rotorua, 8 May 2012); Cassandra Mason and Sandra Conchie "Schoolgirl violence a concern" Bay of Plenty Times (online ed, Bay of Plenty, 8 July 2013); Rebecca Malcolm "Girls find fighting acceptable" Rotorua Daily Post (online ed, Rotorua, 17 June 2013); Abby Gillies "Mall girls snapped in the act" The New Zealand Herald (online ed, Auckland, 3 April 2011); Amanda Harper "Rise in girl violence alarms" Waikato Times (online ed, Hamilton, 24 July 2010); Ashleigh Stewart "Video of attack on girl 'sickening"' The Press (online ed, Christchurch, 7 January 2014).

33 Tess McClure "Girls behaving badly" The Press (online ed, Christchurch, 3 November 2013). 
Experts say disenfranchised, displaced and inebriated young women are lashing out to take control in their homes and on the streets. Overall, youth crime in New Zealand is at a record low, with offending down more than a third since 1995, but aggressive girls are bucking the trend.

This report displays elements of the "liberation hypothesis", notably that girls' violence is catching up with those of boys. Further to this theme, an article in the Rotorua Daily Post noted that "school counsellors say girls have become more violent in the past 15 years and boys have become less violent, apparently reflecting feminist messages in popular media". ${ }^{34}$ Another familiar theme is that girls' violence stems from deviant sexuality. A 2009 article (entitled "'Barbie bitches' plague school playgrounds") ${ }^{35}$ stated that "the 'Barbie Bitches' syndrome had compounded violence among girls, as they tried balancing desires to be attractive with being tough and mean". Another described violent behaviour as the "new 'sexy"' for teenage girls. ${ }^{36}$

\section{THE STATISTICAL PICTURE}

\section{A Operation of the Youth Justice System}

As discussed, perusal of contemporary media reporting would suggest that girls' violence is increasing greatly in both frequency and gravity. Before considering the statistical picture of girls' offending, and examining the question of whether violent offending by this group is in fact increasing, it is necessary to provide a brief overview on the operation of the New Zealand youth justice system. ${ }^{37}$

The age of criminal responsibility in New Zealand is 10 years. ${ }^{38}$ Those aged $10-13$ years are referred to as "children",39 while those aged 14-16 are termed "young persons". ${ }^{40}$ Ten and 11 year olds may only be prosecuted for homicide and then in the adult court system. ${ }^{41}$ Twelve and 13 year olds may be prosecuted in the Youth Court for certain serious and/or persistent offending (mainly

34 Collins and Tapaleao, above n 32.

35 "'Barbie bitches' plague school playgrounds" The Press (online ed, Christchurch, 24 May 2008).

36 Natalie Akoorie "Violence is the new sexy for teen girls" The New Zealand Herald (online ed, Auckland, 10 August 2013); Kiri Gillespie and Teuila Fuatai "'Kick-ass' women in media blamed for violent offending" The New Zealand Herald (online ed, Auckland, 30 March 2012). See also Sally Kidson "Teen girls sucked into crime by older men" (6 February 2010) Stuff.co.nz <www.stuff.co.nz>.

37 For a comprehensive overview of the New Zealand youth justice system, see Nessa Lynch Youth Justice in New Zealand (Thomson Reuters, Wellington, 2012).

38 Crimes Act 1961, s 21.

39 Children, Young Persons, and Their Families Act 1989, s 2(1) definition of "child".

40 Children, Young Persons, and Their Families Act 1989, s 2(1) definition of "young person".

41 Children, Young Persons, and Their Families Act 1989, s 272(1)(a). 
offences of interpersonal violence) ${ }^{42}$ The presumption of doli incapax applies to those aged 10 to 13 years. ${ }^{43}$ From the age of 14 , young persons may be prosecuted for all type of offences, with the majority of offences dealt with in the specialised Youth Court. ${ }^{44}$ Homicide is always within the jurisdiction of the High Court, ${ }^{45}$ while other more serious offences may be dealt with in the District Court. ${ }^{46}$ Transfer out to the District Court is available from age $14 .{ }^{47}$ A key feature of the New Zealand youth justice system is the emphasis on diversion, with the clear majority of apprehensions disposed of without recourse to prosecution. ${ }^{48}$ Diversionary mechanisms include Police warnings, the Police Youth Diversion Scheme, family group conferences and absolute discharges under s 282 of the Children, Young Persons, and Their Families Act 1989. ${ }^{49}$

\section{B General Crime Trends}

It must first be acknowledged that crime is trending downwards in New Zealand. ${ }^{50}$ For children and youth, the apprehension rate (an "apprehension" refers to any time a child or youth is dealt with by the Police in relation to an offence, ranging from no action through diversionary responses to prosecution), has also remained steady or trending downwards in the last decade or so. ${ }^{51}$

42 Children, Young Persons, and Their Families Act 1989, s 272(1)(b) and (c). Until 1 October 2010, children aged 12 to 13 years could only be charged with homicide or minor traffic offences. This position was changed under the Children, Young Persons, and Their Families (Youth Courts Jurisdiction and Orders) Amendment Act 2010.

43 Crimes Act 1961, s 22(1).

44 See s 272(3) of the Children, Young Persons, and Their Families Act 1989, which states that any young person charged with an offence other than homicide, an infringement offence against the Psychoactive Substances Act 2013, a traffic offence not punishable by imprisonment, or an infringement offence against the Sale and Supply of Alcohol Act 2012 or the Summary Offences Act 1981, or s 239A of the Local Government Act 2002, shall be brought before the Youth Court.

45 Children, Young Persons, and Their Families Act 1989, s 275(2)(b).

46 Children, Young Persons, and Their Families Act 1989, s 283(o)(i).

47 Children, Young Persons, and Their Families Act 1989, s 283(o)(i)(B).

48 Ministry of Justice Trends in Child and Youth Prosecutions in New Zealand 2002-2011 (July 2012) at [2.1].

49 See Andrew Becroft "Youth Justice - The New Zealand Experience: 'Past Lessons and Future Challenges"' (paper presented to the Australian Institute of Criminology/NSW Department of Juvenile Justice, Juvenile Justice Conference, Sydney, 2 December 2003) at 14-18.

50 New Zealand Police Annual Report 2012/2013 (2013) at Figure 2.

51 Ministry of Justice Trends for Children and Youth in the New Zealand Justice System 2001-2010 (March 2012) at 5; Ministry of Justice Child and youth prosecutions - trends for 2012/13 (June 2013) at 2. 


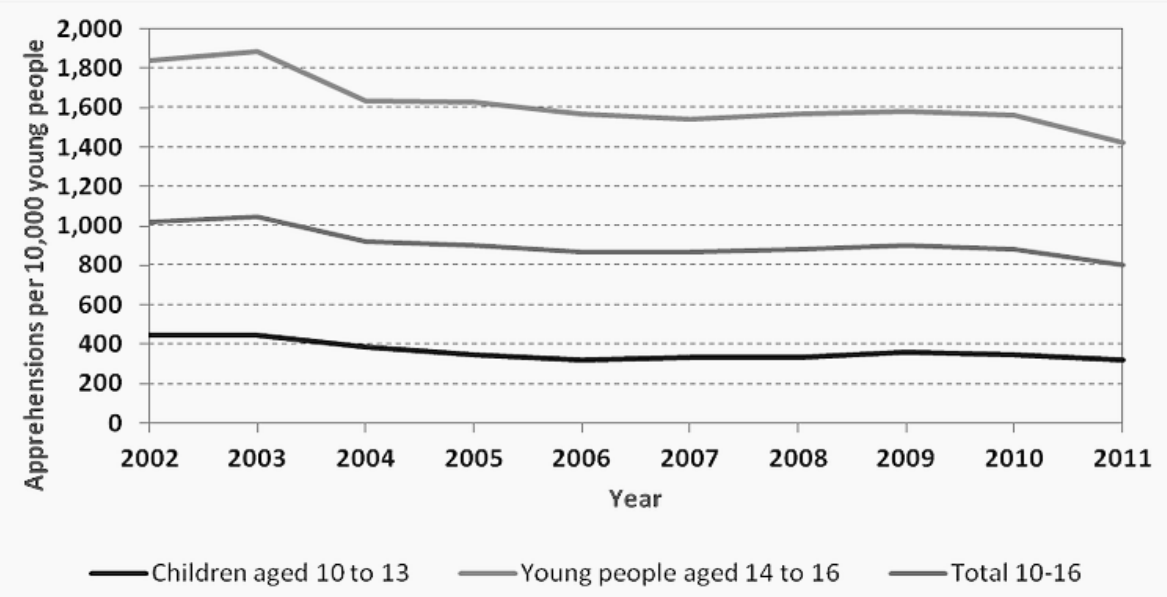

Figure 1: Police apprehension rates (per 10,000 for children and young people by age group, 2002 to 2011) $)^{52}$

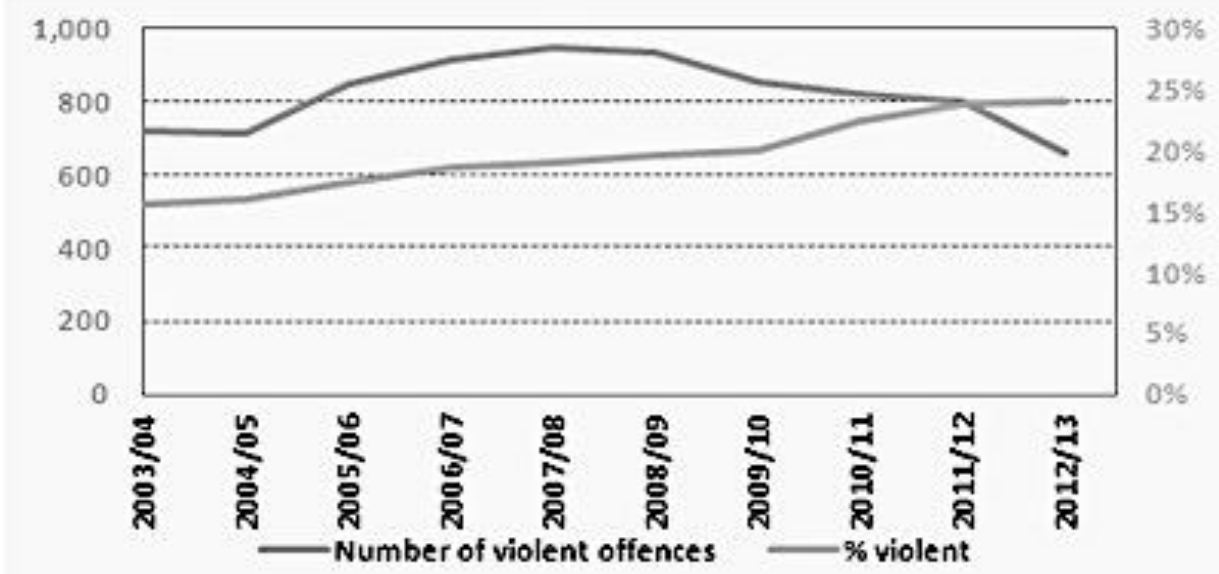

Figure 2: Number and percentage of violent offences by children and young people, 2003/2004 to 2012/2013 ${ }^{53}$

52 Ministry of Justice Trends in Child and Youth Prosecutions in New Zealand 2002-2011, above n 48, at Figure 2.

53 Ministry of Justice Child and youth prosecutions - trends for 2012/13, above n 51. 
While the majority of offending carried out by children and youth are offences involving property (such as vandalism, graffiti, shoplifting, other theft offences and car conversion), ${ }^{54}$ the rate of violent offending by children and young persons has generally trended upwards in the earlier part of the decade, with a decline since 2009. The New Zealand system for recording offences considers violent offences to be homicide and related offences, acts intended to cause injury, abduction and kidnapping, deprivation of liberty/false imprisonment and robbery. ${ }^{55}$

\section{Gender-Specific Statistics}

As discussed, there is an almost complete lack of research on the particular situation of girls in conflict with the law in New Zealand. Gender-breakdown of statistics is not freely available. Both the Police and the Principal Youth Court Judge noted in a 2009 interview that a lack of specific statistics hinders the understanding of, and response to, girls' offending. ${ }^{56}$ The statistics presented here were derived from the raw data available on the Statistics New Zealand website or obtained directly from the Ministry of Justice.

It must first be noted that girls are very much under-represented in the apprehension statistics. Ministry of Justice figures show that, in 2010, 78 per cent of all children and young people apprehended by Police were male, while only 22 per cent were female, though the gap was slowly lessening since $2001 .{ }^{57}$ In 2013, 82 per cent of children and young people charged in court were male, while only 18 per cent were female. ${ }^{58}$ Thus, offending by girls makes up a small minority of youth offending.

\begin{tabular}{|l|l|l|l|l|l|l|l|l|l|}
\cline { 2 - 9 } \multicolumn{1}{c|}{} & $\begin{array}{l}1994 \\
/ 95\end{array}$ & $\begin{array}{l}1995 \\
/ 96\end{array}$ & $\begin{array}{l}1996 \\
197\end{array}$ & $\begin{array}{l}1997 \\
/ 98\end{array}$ & $\begin{array}{l}1998 \\
/ 99\end{array}$ & $\begin{array}{l}1999 \\
/ 00\end{array}$ & $\begin{array}{l}2000 \\
/ 01\end{array}$ & $\begin{array}{l}2001 \\
/ 02\end{array}$ & $\begin{array}{l}2002 \\
/ 03\end{array}$ \\
\hline Apprehensions & 9048 & 9697 & 9185 & 8742 & 9244 & 9820 & 10252 & 9730 & 10097 \\
\hline $\begin{array}{l}\text { Rate per } \\
\mathbf{1 0 , 0 0 0}\end{array}$ & $\mathbf{5 0 3}$ & $\mathbf{5 3 1}$ & $\mathbf{4 9 6}$ & $\mathbf{4 6 6}$ & $\mathbf{4 8 5}$ & $\mathbf{5 0 4}$ & $\mathbf{5 1 3}$ & $\mathbf{4 7 6}$ & $\mathbf{4 8 3}$ \\
\hline
\end{tabular}

54 Ministry of Justice Trends for Children and Youth in the New Zealand Justice System 2001-2010, above n 51 , at 7 and 10 .

55 Australian Bureau of Statistics "Australian and New Zealand Offence Classification (ANZSOC, 2011)" (2 June 2011) <www.abs.gov.au>

56 "More girls committing violent crime, says judge" (13 February 2009) Radio New Zealand News <www.radionz.co.nz>.

57 Ministry of Justice Trends for Children and Youth in the New Zealand Justice System 2001-2010, above $\mathrm{n}$ 51 , at 5 .

58 Ministry of Justice Child and youth prosecutions - trends for 2012/13, above n 51, at 2. 


\begin{tabular}{|l|l|l|l|l|l|l|l|l|l|l|}
\cline { 2 - 10 } \multicolumn{1}{c|}{} & $\begin{array}{l}2003 \\
104\end{array}$ & $\begin{array}{l}2004 \\
/ 05\end{array}$ & $\begin{array}{l}2005 \\
/ 06\end{array}$ & $\begin{array}{l}2006 \\
/ 07\end{array}$ & $\begin{array}{l}2007 \\
/ 08\end{array}$ & $\begin{array}{l}2008 \\
/ 09\end{array}$ & $\begin{array}{l}2009 \\
/ 10\end{array}$ & $\begin{array}{l}2010 \\
/ 11\end{array}$ & $\begin{array}{l}2011 \\
/ 12\end{array}$ & $\begin{array}{l}2012 \\
/ 13\end{array}$ \\
\hline Apprehensions & 9735 & 8902 & 9401 & 8901 & 9505 & 9274 & 10108 & 8854 & 7876 & 6627 \\
\hline Rate per 10,000 & $\mathbf{4 5 8}$ & $\mathbf{4 1 6}$ & $\mathbf{4 3 7}$ & $\mathbf{4 1 6}$ & $\mathbf{4 5 1}$ & $\mathbf{4 4 7}$ & $\mathbf{4 9 1}$ & $\mathbf{4 3 4}$ & $\mathbf{3 9 1}$ & $\mathbf{3 3 6}$ \\
\hline
\end{tabular}

\section{Figure 3: Total females aged 10 to 16 apprehended ${ }^{59}$}

The figures for the apprehension rate demonstrate that apprehensions of girls have tracked the general rate, declining from a high of 531 per 10,000 in 1995/96. There was a spike in 2009/10 but 2011 to 2013 has seen the lowest apprehension rates in 20 years.

\begin{tabular}{|l|l|l|l|l|l|l|l|l|l|}
\cline { 2 - 9 } \multicolumn{1}{c|}{} & $\begin{array}{l}1994 \\
195\end{array}$ & $\begin{array}{l}1995 \\
/ 96\end{array}$ & $\begin{array}{l}1996 \\
/ 97\end{array}$ & $\begin{array}{l}1997 \\
/ 98\end{array}$ & $\begin{array}{l}1998 \\
/ 99\end{array}$ & $\begin{array}{l}1999 \\
/ 00\end{array}$ & $\begin{array}{l}2000 \\
/ 01\end{array}$ & $\begin{array}{l}2001 \\
/ 02\end{array}$ & $\begin{array}{l}2002 \\
/ 03\end{array}$ \\
\hline Apprehensions & 806 & 848 & 853 & 730 & 903 & 938 & 1080 & 1005 & 1050 \\
\hline Rate per 10,000 & $\mathbf{4 5}$ & $\mathbf{4 6}$ & $\mathbf{4 6}$ & $\mathbf{3 9}$ & $\mathbf{4 7}$ & $\mathbf{4 8}$ & $\mathbf{5 4}$ & $\mathbf{4 9}$ & $\mathbf{5 0}$ \\
\hline
\end{tabular}

\begin{tabular}{|l|l|l|l|l|l|l|l|l|l|l|}
\cline { 2 - 10 } \multicolumn{1}{c|}{} & $\begin{array}{l}2003 \\
104\end{array}$ & $\begin{array}{l}2004 \\
/ 05\end{array}$ & $\begin{array}{l}2005 \\
/ 06\end{array}$ & $\begin{array}{l}2006 \\
/ 07\end{array}$ & $\begin{array}{l}2007 \\
/ 08\end{array}$ & $\begin{array}{l}2008 \\
/ 09\end{array}$ & $\begin{array}{l}2009 \\
/ 10\end{array}$ & $\begin{array}{l}2010 \\
/ 11\end{array}$ & $\begin{array}{l}2011 \\
/ 12\end{array}$ & $\begin{array}{l}2012 \\
/ 13\end{array}$ \\
\hline Apprehensions & 1109 & 1163 & 1189 & 1290 & 1382 & 1464 & 1657 & 1481 & 1345 & 1156 \\
\hline Rate per 10,000 & $\mathbf{5 2}$ & $\mathbf{5 4}$ & $\mathbf{5 5}$ & $\mathbf{6 0}$ & $\mathbf{6 6}$ & $\mathbf{7 1}$ & $\mathbf{8 1}$ & $\mathbf{7 3}$ & $\mathbf{6 7}$ & $\mathbf{5 8}$ \\
\hline
\end{tabular}

Figure 4: Females aged 10 to 16 apprehended for violent offences ${ }^{60}$

This graph demonstrates that the rate of apprehension of girls for violent offences has trended slowly upwards from 1994 to 2009/10, reaching a high of 81 per 10,000 population in 2009/10, but has rapidly declined from 2009 to present.

59 Statistics obtained directly from Ministry of Justice. See Email from Adrian Angus (Data Analyst, Information and Analysis, Ministry of Justice) to Nessa Lynch regarding youth justice statistics (29 January 2014)

60 Statistics obtained directly from Ministry of Justice. See Email from Adrian Angus (Data Analyst, Information and Analysis, Ministry of Justice) to Nessa Lynch regarding youth justice statistics (29 January 2014). 


\begin{tabular}{|c|c|c|}
\hline Year & Total Outcomes & Conviction \\
\hline 2011 & 35.9 & 1.92 \\
\hline 2010 & 41.27 & 3.51 \\
\hline 2009 & 44.64 & 3.93 \\
\hline 2008 & 48.33 & 4.3 \\
\hline 2007 & 48.41 & 6.07 \\
\hline 2006 & 43.97 & 4.75 \\
\hline 2005 & 38.29 & 5.03 \\
\hline 2004 & 42.68 & 5.19 \\
\hline 2003 & 39.4 & 5.55 \\
\hline 2002 & 37.17 & 4.94 \\
\hline 2001 & 39.26 & 5.2 \\
\hline 2000 & 37.42 & 6.08 \\
\hline 1999 & 41.32 & 7.33 \\
\hline 1998 & 37.63 & 6.83 \\
\hline 1997 & 38.35 & 7.9 \\
\hline 1996 & 35.56 & 5.87 \\
\hline 1995 & 36.39 & 6.45 \\
\hline 1994 & 29.34 & 5.7 \\
\hline 1993 & 27.37 & 5.04 \\
\hline 1992 & 26.75 & 7.19 \\
\hline
\end{tabular}

Figure 5: Rate of total offences committed by girls between 0-17 years old with outcome (per 10,000 of population) ${ }^{61}$

The conviction rate is a useful measure in determining whether girls are committing top-end violent offences (remembering that the span of the New Zealand definition of violent offence is wide). Conviction and transfer to the District Court or the offer/election of the adult jurisdiction is

61 Statistics derived from the Statistics New Zealand database on file with the author. 
reserved for the most serious offences (formerly known as the purely indictable offences). ${ }^{62}$ This rate has been steady or declining since 1992 . The sharp fall since 2010 is probably related to broader sanctions being available in the Youth Court jurisdiction after legislative reform that year, thus resulting in judicial willingness to retain young persons in the youth justice system. ${ }^{63}$

\section{ANALYSIS}

This article set out to question whether violence by girls in New Zealand is indeed increasing. As noted, it must be remembered that offending by girls makes up less than a fifth of child and youth offending. Consideration of the gender-specific statistics demonstrates that the apprehension of girls for all offences is trending downwards, with the last three years showing the lowest rates in 20 years. This is similar to the trend for adults and for the general child/youth rate. However, the rate of apprehension of girls for violent offences has increased steadily in the last 20 years, reaching a high in $2009 / 10$. In a positive development, the rate has declined sharply to 2013 returning to 2006/2007 levels.

The simplest explanation for the increase in apprehensions over the last 20 years is patently that girls are getting more violent. ${ }^{64}$ It is indisputable that a rise in actual violence accounts for some of the increase in apprehensions. The literature on young female violence appears to shy away from acknowledging this aspect, preferring instead to offer feminist analyses of the labelling of girls as violent. ${ }^{65}$ As Carrington argues, this reluctance to engage in analysis of female violence through a feminist lens has left a "discursive space for anti-feminist sentiment to reign". 66

The evidence suggests, however, that increases in apprehension rates may also be due to changes in recording practices, Police practices and changing societal attitudes. A 2008 report by the Ministry of Justice noted that the trend upwards in apprehensions for violent offending (for all children and youth) may not automatically or definitively mean that the actual rate of violent offending in society is increasing. It was noted that explanations for the increase may also include "changes in Police recording practices, including changes in Police's crime recording IT system in 2005", "reduced public tolerance of family violence and hence increased propensity to report to Police", and a "concomitant change in Police attitudes towards and focus on family violence,

62 Lynch, above n 37, at [9.3].

63 Lynch, above n 37, at [9.3]; Nessa Lynch "Playing catch-up? Recent reform of New Zealand's youth justice system" (2012) 12 Criminology and Criminal Justice 507.

64 See Anselm Blumer and others "Occam's Razor" (1987) 24 Information Processing Letters 377.

65 Gilly Sharpe Offending Girls: Young Women and Youth Justice (Routledge, Oxon, 2013).

66 Kerry Carrington "Girls and Violence: The Case for a Feminist Theory of Female Violence" (2013) 2(2) IJCJ 63 at 63 . 
combined with changes in recording practices" ${ }^{67}$ It must be noted that the raw numbers are quite small, in the 1,000 to 1,500 range. Thus even a small change in Police decision making practice would have a large impact.

An increased focus on family violence in New Zealand in the last decade is likely to have had an effect on the apprehension rate for girls. ${ }^{68}$ It is known that girls are more likely to commit their acts of violence within a family or close personal contact context, whereas boys are more likely to be violent in a street violence setting. ${ }^{69}$ Studies in other jurisdictions have offered other gender-specific explanations for increased apprehension rates for girls. In an echo of the liberation hypothesis, it may be argued that in contemporary society girls have increased freedom and mobility, and are increasingly free from gendered expectations. ${ }^{70}$ This may lead to increased opportunities and motivations for violent behaviour. It has also been suggested that the "chivalry effect" 71 is diminishing as a result of greater equality between the sexes. In the past, violence by girls may have been dealt with through informal means such as family disciplinary methods, while it is possible that more instances are now dealt with through the formal mechanisms of the criminal justice system. ${ }^{72}$

The rapid decrease in apprehensions of girls for all offences and for violent offences since 2009/10 is to be welcomed. A new approach under the 2010 amendments to the Children, Young Persons and Their Families Act 1989 has increased powers to deal with serious and persistent offending by 12 and 13 year old children, as well as new reintegrative Youth Court orders, including orders for parents and guardians. ${ }^{73}$ It is likely that this legislative focus as well as an increased focus

67 Ministry of Justice Improving Interventions to Reduce Violent Offending by Young People in New Zealand (August 2008) at Appendix One.

68 For official reports focussing on the issue of family violence in New Zealand, see Ministry of Social Development Te Rito: New Zealand Family Violence Prevention Strategy (2002); Janet Lynn Fanslow Beyond Zero Tolerance: Key Issues and Future Directions for Family Violence Work in New Zealand (Families Commission, 2005).

69 See Gerald T Hotaling, Murray A Straus and Alan J Lincoln "Intrafamily Violence, and Crime and Violence Outside the Family" (1989) 11 Crime \& Just 315.

70 See Jody Miller One of the Guys: Girls, Gangs, and Gender (Oxford University Press, New York, 2001).

71 Christy A Visher "Gender, Police Arrest Decisions, and Notions of Chivalry" (1983) 21 Criminology 5 at 6 and 24.

72 See Joy Wundersitz, Ngaire Naffine and Fay Gale "Chivalry, Justice or Paternalism?: The Female Offender in the Juvenile Justice System" (1988) 24 Journal of Sociology 359; William A Reese II and Russell L Curtis Jr "Paternalism and the Female Status Offender: Remanding the Juvenile Justice Double Standard for Desexualization" (1991) 28 The Social Science Journal 63.

73 Lynch, above n 63. 
on youth under the Fresh Start policy, ${ }^{74}$ has influenced a decline in youth offending. As noted, the numbers of apprehensions of girls for violent offending are small. Successful desistance from violent offending by a small number of girls would change the rate hugely.

\section{CONCLUDING REMARKS}

It is evident that there is no empirical data to suggest that the rate of violent offending by girls should give cause for major concern. The rate of apprehension for all offences is trending downwards and for violent offences has fallen sharply in the last three reporting years. The raw numbers are small, and are thus sensitive to policy imperatives such as changes in Police practice. It appears as if a popular (and possibly professional) perception of an increasing number of violent girls is driven by anecdote rather than evidence.

Despite the positive developments in decreasing numbers of apprehensions, a pressing issue is the lack of gender-specific research which considers the offending profiles and background of young female offenders. The lack of an empirical New Zealand-specific foundation means that the issue is apparently ignored at the policy level. The Government's Youth Crime Action Plan, ${ }^{75}$ which contains comprehensive actions to be taken in the 2013 to 2015 period, has no mention of specific programmes or research on the particular situation of girls. There is also a notable lack of femalespecific rehabilitative and re-integrative programmes in New Zealand.

74 Child, Youth and Family A Fresh Start for Young Offenders (Ministry of Social Development, CYF145, August 2010).

75 Ministry of Justice Youth Crime Action Plan 2013-2023 (2013). 
